\title{
The Employee Performance Seen from the Aspects of Organizational Culture and Commitment at the Education Office of Pematangsiantar City
}

\author{
Novita Butarbutar \\ Sekolah Tinggi Ilmu Ekonomi Sultan Agung \\ novita@stiesultanagung.ac.id

\section{Erbin Chandra} \\ Sekolah Tinggi Ilmu Ekonomi Sultan Agung \\ erbinchandra@stiesultanagung.ac.id

\section{Grace Endang Pakpahan} \\ Sekolah Tinggi Ilmu Ekonomi Sultan Agung \\ gracepakpahan@stiesultanagung.ac.id
}

\begin{abstract}
Abstrak The objective of this study was to determine the effect of organizational culture and commitment to employee performance at the Education Office of Pematangsiantar City. This study used literature and field research designs. The research method used was the causality method with a quantitative approach. The type of data used in this study was qualitative data and quantitative data. The data sources consisted of primary data and secondary data. The population and sample used in this study were 81 permanent employees. The data collection was carried out by questionnaire, interview and documentation. The analysis technique used was qualitative descriptive and quantitative descriptive analysis consisting of multiple linear regression, correlation test and determination and hypothesis tests. The results of this study concluded that the organizational culture, commitment and employee performance were good. Besides, the organizational culture had a positive and significant effect on employee performance. Furthermore, the commitment had a positive and significant effect on employee performance.
\end{abstract}

Kata Kunci Organizational Culture, Commitment, Employee Perfomance

\section{INTRODUCTION}

Companies and organizations are categorized as good when they have quality 
human resource assets and carry out work optimally so that the target of the companies and organizations can be achieved (Sahir et al., 2020). Human resources are a very important element and must be possessed in efforts to achieve organizational goals. Human resources are proactive individuals who work as activators of an organization, both within institutions and companies that have the function as assets, so their abilities must be trained and developed. Participation and role of human resources or commonly referred to as workers or employees is the most crucial factor to achieve company and organizational goals (Shahzad, 2014). Employee performance is the result of work done by an employee in order to achieve organizational goals. According to Zainal, et al. (2015), performance is a program to test how well employees perform their duties compared to several standards, and then provides information related to matters relating to communication to other employees. Based on (Putri, Isnanindia, 2016) study, every employee should have time discipline so that every duty related to performance improvement can be achieved. Basically, the level of an individual's performance is different depending on the level of ability owned by the individual in carrying out and completing their respective duties (Efendy, Herlambang and Rozaid, 2018).

Based on the results of the interview with the Head of the General Subdivision at the Education Office of Pematangsiantar City, it is known that the employee performance at the Education Office of Pematangsiantar City is still not optimal. It can be seen that there is still a percentage with a poor category of $5 \%$ and a moderate category of $25 \%$. In the dimension of the employee's work target, it is due to the fact that there are employees whose work level has not reached the set time. This is because in completing duties and responsibilities, employees rarely attend and leave early which can cause completion of the duty to be delayed. Whereas in the dimension of work behavior, there are still some employees whose level of attendance is not in accordance with predetermined regulations, such as arriving at the office not on time and often absent, as well as problems that occur in relations between employees that are not good enough, such as problems of employee dissatisfaction of a sense of fairness in the organization when one employee must work or be responsible for the negligence of the work of other employees in the work team.

The phenomenon of organizational culture at the Education Office of Pematangsiantar City shows that it is not optimal in the dimension of the rules, which is due to the fact that there are still employees who are not on time to arrive at the office hours and leave early so that they do not follow the morning meeting and there are work constraints. In the dimension of the norm, it is not yet optimal, caused by a lack of cooperation between employees and they show ignorance among coworkers, resulting in differences or misunderstanding between employees. The phenomenon of commitment at the Education Office of Pematangsiantar City in the dimension of affective commitment is not yet optimal, as seen that employees not accepting the opinions of their coworkers, resulting in disputes or misunderstanding between employees and lack of enthusiasm in working because they consider it a normal routine. In the dimension of normative commitment, it is not optimal because there are still employees who do not obey the rules set in the organization, causing unfairness to other employees. In several perspectives related to the commitment and performance of the organization that is correlated, it can be proofed that the intention of leaders to bring change through the role of transformational leadership and empowerment efforts is supported by commitment and trust, or vice versa, it may not be actualized without the confidence of employees that the leaders will do what they say (Saleem et al., 2019) Therefore, commitment is influential for organizations to achieve organizational goals and the sustainability of company goals (Sari, 2018).

\section{LITERATURE REVIEW}

\subsection{Organizational Culture}

One of the factors that is predicted to affect the level of an individual's 
performance is organizational culture. Organizational culture is a method and values adopted in an organization that can be correlated to the environment in which the organization carries out its activities well. According to Kreitner and Angelo (2014), organizational culture is a set of assumptions shared and accepted implicitly and held by a group that determines how it is felt, thought, and acted on diverse environments. Organizational culture may be assessed in several dimensions, so it is conceptually different but basically similar in the concept of models and theories (Yiing and Ahmad, 2009). Organizational culture is a characteristic, reference and differentiator that must be upheld by the organization. Based on some opinions of the experts above, the authors conclude that organizational culture is a view of fostering confidence on the basis agreed and followed by every individual in the group to realize good work achievement.

\subsection{Commitment}

Every organization still needs employees as part of the office. However, in becoming part of an organization, employees need to be trained to have commitment. Commitment becomes an important role in the organization, so that employees who have commitment become a supporting factor in carrying out the duties and responsibilities within the organization. According to Luthans (2006), "commitment is a strong desire to try to be in the members of the organization, full recognition, as the true attitude of the character that comes out of an individual". Commitment is employee loyalty in working and eager to maintain high concern for an organization. Based on the opinions of the experts above, it can be concluded that commitment is job satisfaction, the level of trust or desire to remain in the organization, as well as a strong desire to achieve organizational goals. A commitment to the organization will make an individual have an emotional interest in the organization so that it can be used as an indicator to show the individual's performance (Joko, Munir and Fattah, 2019)

\subsection{Employee Perfomance}

The Education Office of Pematangsiantar City is a government agency that has the main tasks and functions in the form of fostering, supervising and facilitating the implementation of formal and non-formal education managed by the government or the community from pre-school and basic education levels in coordination with the Pematangsiantar City government. Thus, the relationship between superiors and subordinates in carrying out their duties is required to be fostered to generate convenience in achieving optimal performance that has implications for organizational goals to be achieved (Sahir et al., 2020). The employee performance at the Education Office of Pematangsiantar City is assessed based on Government Regulation Number 46 of 2011 concerning Employee's Work Target (SKP) and Work Behavior (PK).

\section{METHOD}

In this study, the authors used literature and field research designs. The research method used was the causality method with a quantitative approach. The research object was employees of the Education Office of Pematangsiantar City. The type of data used was qualitative and quantitative data. The data sources were from primary data and secondary data. The research data were collected by conducting interviews, documentation and distributing questionnaires. The data analysis included qualitative data analysis and quantitative data analysis.

\section{RESULT}

\subsection{The Organizational Culture Overview at the Education Office of Pematangsiantar City}


Overall, it can be seen that the recapitulation of the respondents' answers is 3.63. It shows a high average value of 3.90 with strong answer criteria in the dimension of philosophy with an indicator of respect among fellow employees. While the lowest average value is 2.88 with quite strong answer criteria in the dimension of the norm with an indicator of the behavior of fellow employees within the agency.

\subsection{The Commitment Overview at the Education Office of Pematangsiantar City}

Of the total respondents' answers regarding affective commitment, continuous commitment and normative commitment obtained an average value of 3.69 with high answer criteria. Then, it shows the highest average value of 3.91 with high answer criteria in the dimension of normative commitment with an indicator of employee responsibility while working for the agency. While the lowest average value is 3.30 with quite high answer criteria in the dimension of affective commitment with an indicator of employee involvement in solving problems in the organization.

\subsection{The Employee Performance Overview at the Education Office of Pematangsiantar City}

Of the total respondents' answers regarding the dimension of the employee's work target and work behavior, it obtained an average value of 3.83 with good answer criteria. Then, the highest average value is 4.38 with very good answer criteria for the dimension of work behavior with an indicator of ability to direct. While the lowest average value is 2.88 with fairly good answer criteria for the dimension of work behavior with an indicator of the level of attendance.

\subsection{Quantitative Descriptive Analysis}

\subsubsection{Multiple Linear Regression Analysis}

To analyze the influence of organizational culture $\left(\mathrm{X}_{1}\right)$ and commitment $\left(\mathrm{X}_{2}\right)$ on employee performance (Y) at the Education Office of Pematangsiantar City, the calculation of data analysis used SPSS version 21, so the following regression results were obtained:

Table 1

Simple Linear Regression Results

\begin{tabular}{|l|r|r|r|}
\hline \multirow{2}{*}{ Model } & \multicolumn{2}{|c|}{$\begin{array}{c}\text { Unstandardized } \\
\text { Coefficients }\end{array}$} & Standardized Coefficients \\
\cline { 2 - 5 } & \multicolumn{1}{|c|}{ B } & Std. Error & \multicolumn{1}{c|}{ Beta } \\
\hline (Constant) & 17.760 & 5.591 & \\
1 \\
$\begin{array}{l}\text { Organizational } \\
\text { Culture }\end{array}$ &, 353 &, 097 &, 297 \\
\hline Commitment & 1,098 &, 155 &, 579 \\
\hline
\end{tabular}

a. Dependent Variable: Employee Performance

Source: SPSS Statistics version 21 (2019)

Based on the results of regression with SPSS version 21 in table 2 above, it obtained a regression coefficient of $b_{1}$ of 0.353 and $b_{2}$ of 1.098 so that it can be seen that the regression equation obtained is $\hat{\mathrm{Y}}=17.760+0.353 \mathrm{X}_{1}+1.098 \mathrm{X}_{2}$, meaning that there 
is a positive effect between organizational culture and commitment to employee performance at the Education Office of Pematangsiantar City.

\subsubsection{Correlation Analysis and Coefficient of Determination}

To determine the strength of the relationship between organizational culture and commitment to employee performance, a correlation analysis was carried out in the form of degrees or depth of functional relationships that explained the relationship between the $\mathrm{r}$ value. In calculating and determining the correlation value and the coefficient of determination value, the SPSS program version 21 was used to see the values. The following table presents the results of calculating the correlation value and the coefficient of determination value:

Table 2

Correlation Coefficient and Coefficient of Determination

\begin{tabular}{|l|r|r|r|r|}
\hline Model & \multicolumn{1}{|c|}{$\mathrm{R}$} & R Square & Adjusted R Square & Std. Error of the Estimate \\
& & & & \\
\hline 1 & $.755^{\mathrm{a}}$ & .570 & .559 & 4.595 \\
\hline
\end{tabular}

a. Predictors: (Constant), Organizational Culture, Commitment

b. Dependent Variable: Employee Performance

Source: SPSS Statistics version 21 (2019)

Based on the results of the regression analysis with SPSS in table 3 above, a correlation of $r=0.755$ is obtained, which means that there is a significant and positive relationship between organizational culture and commitment to employee performance at the Education Office of Pematangsiantar City. The coefficient of determination is 0.570 which means that the quality of employee performance can be explained by $57 \%$ by organizational culture and commitment and the remaining $43 \%$ is explained by other factors, such as leadership, motivation, work environment, etc.

\subsubsection{Hypothesis testing}

This test is carried out simultaneously to determine whether a hypothesis is accepted or rejected. Hypothesis testing is done to determine whether the variables of organizational culture and commitment tested affect employee performance. If $F_{\text {count }}>$

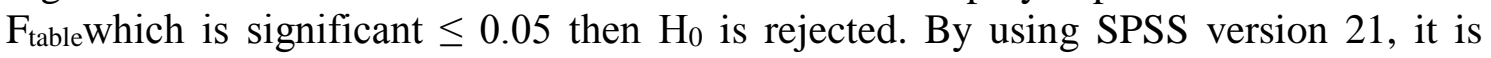
obtained an $\mathrm{F}_{\text {count }}$ from the calculation results as follows:

Table 3

The estimated value of $F_{\text {count }}$

\begin{tabular}{|l|l|c|c|}
\hline Model & Sum of Squares & $\mathrm{F}$ & Sig \\
\hline Regression & 2183.454 & 51.710 & $.000^{\mathrm{b}}$ \\
\hline Residual & 1646.768 & & \\
\hline Total & 3830.22 & & \\
\hline
\end{tabular}

Source: SPSS Statistics version 21 (2019)

Based on table 4 above, it obtained $F_{\text {count }}$ of $51.710>F_{\text {table }}(0.05,2$ vs 78$)$ of 3.05 or with a significant level of $0.000<\alpha$ which means that organizational culture and commitment have a positive and significant effect on employee performance at the Education Office of Pematangsiantar City. 
The next test is the $\mathrm{t}$ test. This test is carried out partially to determine whether the hypothesis is accepted or rejected. The effect of the hypothesis is to determine whether the variables of organizational culture and commitment tested have an effect on employee performance. If $t_{\text {count }}>t_{\text {table }}$ is significant $\alpha \leq 0.05$ then $\mathrm{H}_{0}$ is rejected. To test the truth, hypothesis testing was carried out using SPSS version 21.

\section{Table 4}

The estimated value of $t_{\text {count }}$

\begin{tabular}{|c|c|c|}
\hline Model & $\mathrm{t}$ & Sig \\
\hline Constant & 3.177 & \\
\hline Organizational Culture & 3.627 & 0.001 \\
\hline Commitment & 7.064 & 0.000 \\
\hline
\end{tabular}

Source: SPSS Statistics version 21 (2019)

Based on table 5 above, it can be seen that the $t_{\text {count }}$ of the organizational culture variable $\left(\mathrm{X}_{1}\right)$ is 3.627> $\mathrm{t}_{\text {table }}$ with $\mathrm{df}=\mathrm{n}-\mathrm{k}-1(81-2-1)$ of 1.990 or with a significance level of $0.001 \leq \alpha 0.05$, then $\mathrm{H}_{0}$ is rejected. It means that organizational culture has a positive and significant effect on employee performance at the Education Office of Pematangsiantar City. While $t_{\text {count }}$ on commitment variable $\left(\mathrm{X}_{2}\right)$ is 7.064 and $t_{\text {table }}$ with $\mathrm{df}$ $=\mathrm{n}-\mathrm{k}-1$ (50-2-1) of 1990 or with a significance level of $0.000 \leq \alpha 0.05$, then $\mathrm{H}_{0}$ is rejected. It means that commitment has a positive and significant effect on employee performance at the Education Office of Pematangsiantar City.

\subsection{The Effect of Oganizational Culture on Employee Perfomance}

An invisible social force that can simultaneously drive people in an organization to carry out work activities is a representation of the strengths and weaknesses of the effect of organizational culture on a company or organization. Based on the results of the research above, it is known that organizational culture influences employee performance at the Education Office of Pematangsiantar City. The results are in line with studies conducted by (Usman, 2016), (Pakpahan et al., 2019), (Jamaluddin et al., 2017), (Hadju and Adam, 2019), (Reni and Syamsir, 2019) which stated that organizational culture has a significant effect on performance.

\subsection{The Effect of Commitment on Employee Perfomance}

An important behavior to survive in a company or organization is a commitment that is reflected in the personality of each individual. The commitment that is well managed will have implications for the level of good performance as well, so that the manifestation of an individual's performance can be seen from the level of the individual's seriousness at work. Based on the results of the study above, it is known that commitment has an effect on employee performance at the Education Office of Pematangsiantar City. The results have similarities with the results of studies conducted by (Franco and Franco, 2017), Sari (2018), (Efendy, Herlambang and Rozaid, 2018), (Fitria and Yasa, 2018), (Joko, Munir and Fattah, 2019), (Wetik, Baharuddin and Tamsah, 2018), (Maharisa, Hendriani and Efni, 2017) which stated that commitment has a significant effect on performance. 


\section{CONCLUSION}

The results of multiple linear regression analysis show that there is a positive and significant effect of organizational culture and commitment on employee performance at the Education Office of Pematangsiantar City. The results of correlation analysis show that there is have a significant and positive relationship of organizational culture and commitment to employee performance at the Pematangsiantar City Education Office. Then the analysis of the coefficient of determination shows that the level of employee performance $(\mathrm{Y})$ in the Pematangsiantar City Education Office can be explained in organizational culture $\left(\mathrm{X}_{1}\right)$ and commitment $\left(\mathrm{X}_{2}\right)$. Hypothesis testing results with the $\mathrm{F}$ Test (simultaneous test) obtained $\mathrm{F} \mathrm{H}_{0}$ rejected, meaning that there is a positive and significant influence between organizational culture variables and commitment to employee performance at the Education Office of Pematangsiantar City. The results of hypothesis testing with the $\mathrm{t}$ test (partial test) obtained show that $\mathrm{H}_{0}$ is rejected, meaning that there is a positive and significant effectof organizational culture and commitment to employee performance at the Education Office of Pematangsiantar City partially. Further, suggestions in this study include: to improve the organizational culture at the Education Office of Pematangsiantar City, the employees should be more obedient to regulations and increase good cooperation by showing a caring attitude towards their co-workers. In addition, to improve commitment at the Education Office of Pematangsiantar City, the employees should be more willing to accept the opinions of their co-workers and increase morale at work. Then, to improve employee performance at the Education Office of Pematangsiantar City, the employees should maximize the level of responsibility, ability, attendance and not delay the duty given.

\section{DAFTAR PUSTAKA}

Efendy, M. R. R., Herlambang, T. and Rozaid, Y. (2018) 'Pengaruh Motivasi dan Komitmen Terhadap Budaya Organisasi dan Kinerja Pegawai Pada Kantor Dinas Kependudukan dan Pencatatan Sipil Kabupaten Jember', Jurnal Sains Manajemen dan Bisnis Indonesia, 8(1), pp. 32-46.

Fitria, N. L. and Yasa, A. D. (2018) 'Pengaruh Motivasi Dan Komitmen Terhadap Kinerja Pegawai Negeri Sipil Di Dinas Kebudayaan Provinsi Bali Public Inspiration : Jurnal Administrasi Publik', Jurnal Administrasi Publik, 3(1), pp. 46-52.

Franco, M. and Franco, S. (2017) 'Organizational commitment in family SMEs and its influence on contextual performance', Team Performance Management, 23(7-8), pp. 364-384. doi: 10.1108/TPM-05-2016-0020.

Hadju, L. and Adam, N. (2019) 'Pengaruh Budaya Organisasi Terhadap Kinerja Pegawai Pada Dinas Perhubungan Kabupaten Bone Bolango', Jurnal Manajemen Sumberdaya Manusia, 6(2), pp. 125-135.

Jamaluddin, J. et al. (2017) 'Pengaruh Budaya Organisasi terhadap Kinerja Pegawai pada Dinas Pendidikan Provinsi Sulawesi Selatan', Jurnal Ad'ministrare, 4(1), p. 25. doi: $10.26858 /$ ja.v4i1.3443.

Joko, T., Munir, R. and Fattah, N. (2019) 'Pengaruh Pengembangan Karir, Pengawasan dan Komitmen Terhadap Kinerja Pegawai di Dinas Pengendalian Penduduk dan 
Keluarga Berencana Kabupaten Bantaeng', YUME : Journal of Management, 2(2), pp. 1-15.

Kreitner, Robert and Angelo Kinicki. 2014. Perilaku Organisasi. Volume 1, Ninth Edition. Jakarta: Salemba Empat.

Luthans, Fred. 2006. Perilaku Organisasi. Tenth Edition. Yogyakarta: ANDI.

Maharisa, I., Hendriani, S. and Efni, Y. (2017) 'Analisis Pengaruh Beban Kerja, Komitmen Organisasional dan Pengawasan Terhadap Kinerja Pegawai Pada Badan Pusat Statistik Provinsi Riau Pekanbaru', Procuration: Jurnal Ilmiah Manajemen, 5(2), pp. 251-261. doi: 10.1017/CBO9781107415324.004.

Pakpahan, G. E. et al. (2019). Pengaruh budaya organisasi, komunikasi dan kompetensi guru terhadap kinerja guru sma swasta sultan agung pematangsiantar. Jurnal Kinerja, 16(2), pp. 131-138.

Putri, Isnanindia, S. (2016) 'Pengaruh Budaya Organisasi Terhadap Kinerja Pegawai di Dinas Pendidikan dan Kebudayaan Kota Samarinda.', eJournal Administrasi Negara, 4(4), pp. 4802-4816.

Reni, M. and Syamsir (2019) 'Influence of Organizational Culture on the Performance of Nagari Government Apparatus in Managing Nagari Financial in Tanah Datar Regency', Jurnal Administrasi Negara, 25(1), pp. 72-88. doi: 10.33509/jan.v25i1.539.

Sahir, S. H. et al. (2020). Keterampilan Manajerial Efektif. Cetakan Pertama. Medan: Yayasan Kita Menulis.

Saleem, M. A. et al. (2019) 'Enhancing performance and commitment through leadership and empowerment: An emerging economy perspective', International Journal of Bank Marketing, 37(1), pp. 303-322. doi: 10.1108/IJBM-02-2018-0037.

Sari, P. I. (2018) 'Pengaruh Komitmen dan Disiplin Terhadap Kinerja Pegawai Pada Dinas Perhubungan Provinsi Jambi', Jurnal Manajemen dan Kewirausahaan, 9(2), pp. 54-63. doi: 10.1017/CBO9781107415324.004.

Shahzad, F. (2014) 'Impact of organizational culture on employees' job performance: An empirical study of software houses in Pakistan', International Journal of Commerce and Management, 24(3), pp. 219-227. doi: 10.1108/IJCoMA-07-2012-0046.

Usman, B. (2016) 'PENGARUH BUDAYA ORGANISASI TERHADAP KINERJA PEGAWAI PADA CV. SYABIA MEDIA PALEMBANG', Jurnal Media Wahana Ekonomika, 13(2), pp. 56-67.

Wetik, S. W., Baharuddin and Tamsah, H. (2018) 'Analisis Pengaruh Komitmen dan Integritas terhadap Kinerja melalui Kompetensi Pegawai pada Kantor Kesyahbandaran dan Otoritas Pelabuhan Kota Manado', YUME: Journal of Management, 1(3), pp. 137-151.

Yiing, L. H. and Ahmad, K. Z. Bin (2009) 'The moderating effects of organizational culture on the relationships between leadership behaviour and organizational commitment and between organizational commitment and job satisfaction and performance', Leadership and Organization Development Journal, 30(1), pp. 5386. doi: 10.1108/01437730910927106.

Zainal, et.al. 2015. Manajemen Sumber Daya Manusia Untuk Perusahaan. Edisi Ketiga. Cetakan Ketujuh. Jakarta: Rajawali Pers. 